\title{
DETERMINANTS OF THE FINANCING STRUCTURE OF THE ACQUIRING COMPANIES IN THE PRE-MERGER PERIOD. RESULTS OF THE RESEARCH
}

\author{
Ilona Fałat-Kilijańska ${ }^{1}$, Jana Gláserová ${ }^{2}$, Piotr Luty $^{3}$, Milena Otavová ${ }^{4}$ \\ (C) 2020 Ilona Fałat-Kilijańska, Jana Gláserová, Piotr Luty, Milena Otavová \\ This work is licensed under the Creative Commons Attribution-ShareAlike 4.0 International License. \\ To view a copy of this license, visit http://creativecommons.org/licenses/by-sa/4.0/
}

Quote as: Fałat-Kilijańska, I., Gláserová, J., Luty, P. i Otavová, M. (2020). Determinants of the financing structure of the acquiring companies in the pre-merger period. Results of the research. Financial Sciences, 25(4).

DOI: $10.15611 /$ fins.2020.4.02

JEL Classification: G32, G34

\begin{abstract}
The article's main objective is to identify the factors influencing the financing structure and capital changes in the pre-merger periods in the acquiring companies. The authors examined the relations between various industries and different size companies. Based on the analyses, it can be concluded that in small companies, the explanatory variables identified based on the literature review were statistically insignificant in many periods (in fact almost all). Completely different behaviour was observed in the group of large companies, where the same set of explanatory variables was statistically significant. The result of the research on the existence of non-linear relationships between company parameters is that in the case of some variables, there is no question of a linear nature of dependence. The study analysed the five years preceding the mergers of 307 business entities. The source of the survey data was the database prepared by the company InfoCredit SA for the Accountants Association in Poland. The authors used Statistica software and inductive reasoning for the study - supported by Spearman's rank correlation analysis, linear and polynomial regression analysis, and variable scatter analysis.
\end{abstract}

Keywords: M\&A, financing structure, capital structure.

\section{Introduction}

The process of capital concentration is a crucial stage in companies' operation, requiring specific preparation. Mergers of economic units are considered a form of entity development through external development, i.e. taking over other entities.

${ }^{1}$ Wroclaw University of Economics and Business, Wroclaw, Poland, e-mail: i.falat-kilijanska@ue.wroc.pl, ORCID: 0000-0001-5038-7109.

2 Mendel University in Brno, Brno, Czech Republic, e-mail: jana.glaserova@gmail.com, ORCID: 0000-0001-5038-8347.

3 Wroclaw University of Economics and Business, Wroclaw, Poland, e-mail: piotr.luty@ue.wroc.pl, ORCID: 0000-0003-0955-7000

${ }^{4}$ Mendel University in Brno, Brno, Czech Republic, e-mail: milena.otavova@mendelu.cz, ORCID: 0000-0003-2481-479X. 
Based on statistical data from the report prepared by PARP3 (Polish Agency for Enterprise Development), the authors observed that in the second year of companies' existence, the survival rate is already at $80.1 \%$, and with subsequent years it increased further. In the third and fourth year of activity, companies' survival in the growth phase oscillates around $83 \%$. In the fifth year of companies' existence, microenterprises are most often liquidated (a survival rate at the level of 83.5\%). In large, medium and small companies, the percentage of these liquidated companies is very low - the survival rate is close to $100 \%$.

The need for this type of development often occurs at a company's maturity stage. In most cases, companies initiate a merger, meaning that they are interested in this form of capital concentration.

The article's primary goal is to identify the factors determining the financing structure and its changes in the pre-merger periods in the acquiring companies. The study of the financing structure also requires examining what relations form in various economic activity sectors. The authors reveal whether and how a company's size determines the capital structure. Research on the impact of a company's size on this financial structure indicate that young and small entities have the most problems with access to capital, hence problems with capital availability result in difficulties in maintaining the optimal capital structure. Fixed assets used by companies may, to a certain extent, minimise the risk of a borrower's insolvency, and in this way they become significant collateral for the received funding.

The literature review shows a research gap concerning the shaping of the financing structure in companies preparing for a merger. The authors formulated two main questions for this study. The first one - are different determinants describing the financing structure in acquiring companies in the period preceding the merger? The second one - does the financing structure differ in the groups of small and large companies? Intuitively, due to their nature, small entities may encounter problems with the optimal shaping of the financing structure. However, if one assumes that mergers take place in the mature phase of company development, similar mechanisms may occur in the groups of the studied companies.

The authors examined the five years preceding the mergers of 307 business entities. The survey of data source was the database of InfoCredit SA prepared for the Accountants Association in Poland.

This study used the Statistica software and inductive reasoning - supported by Spearman's rank correlation analysis, linear and polynomial regression analysis, and variable scatter analysis.

\section{Literature review}

The review of literature such as Zhang, Wang, Chen and Wang (2018), suggests that the business combination process may negatively impact the acquirer's business practices. The benefits of a capital concentration should be mutual - for both the acquirer and the target company (Weitzel \& McCarthy, 2011). 
Analyses often show that acquiring companies owe their strength to the good macroeconomic situation and the booming domestic economy. The companies they take over come from countries with a slower economy and in recession. This situation is related to access to financing sources, which are the driving force behind companies' development. Many studies have confirmed this statement (Acharya, Shin, \& Yorulmaz, 2010; Aguiar \& Gopinath, 2005; Desai, Foley, \& Forbs, 2007; Krugman, 2000). The regression analysis (Makaew, 2010) indicated that more cross-border merger transactions were carried out when companies were in good economic conditions. This research covers only domestic capital concentration transactions, and therefore examines the macroeconomic situation's impact in this preliminary study.

Reddy (2015) indicates that in research on capital concentration processes (mergers of companies), including transaction failures, most often the financial aspects - the reduction of value for owners - are analysed in scientific studies. Economic and market data are examined when announcing the intention to merge and after the date of the merger (cf. De Bernardis \& Giustiniano, 2015; McCann \& Ackrill, 2015; Munjal \& Pereira, 2015). Only a few studies indicate improperly conducted negotiations and the preparation of companies for mergers, i.e. periods preceding joining businesses, as the reason for the failure of mergers and acquisitions (cf. Ahammad, Tarba, Liu, Glaister, \& Cooper, 2016; Caiazza \& Volpe, 2015; Friedman, Carmeli, Tishler, \& Shimizu, 2016, as well as Lee, Park \& Kim, 2014). Therefore, this research focuses on the periods preceding the merger of economic entities.

An essential factor shaping capital concentration is the legal environment, which organises many activities related to mergers. Studies on the influence of the legal environment and political transactions, such as Porta, Lopez-de-Silanes, Shleifer and Vishna (1998), Klapper and Love (2004), as well as Feldman and Kumar (1995), were examined. The valuation of the companies' shares is sensitive to the financial information sent by the merging companies. Developing capital markets are characterised by the more significant asymmetry of information and unequal access to financial information. These issues were the research subject for Brunnermeier (2005) and Cornett, McNutt, Strahan and Tehranian (2011). The authors of this article focused on the Polish market to avoid the influence of multinational legal and political factors, however this is a preliminary study that will be extended to include other developing countries from Central and Eastern Europe.

In scientific research, there are many discrepancies about a company's financial condition after a merger, regardless of the motives for conducting merger transactions. The companies and the business environment's internal factors prove that mergers can positively impact on the financial results (Ghosh, 2001; Heron \& Lie, 2002; Linn \& Switzer, 2001; Martynova, Oosting, \& Renneboog, 2006; Powell $\&$ Stark, 2005). Studies show that mergers do not significantly improve the financial situation (Martynova et al., 2006; Moeller \& Schlingemann, 2004). The complexity of the conditions in which entities merge, justifies the need to examine mergers.

There are many publications concerning the field of the shaping of the capital structure. Numerous theories attempt to justify the behaviour of companies in terms of 
the selection of equity or liabilities. For example, based on 11,553 observations of European companies (excluding Polish ones), Castro, Fernandez, Amor-Tapia, and de Miguel (2016) noted that the financing structure (liabilities/total capital) is positively correlated with the operating profitability of assets, asset structure (fixed assets/total assets) and company size (Ln assets). They examined companies in various stages of development (start-up, growth and maturity), and analysed the financing structure determinants using GMM regression analysis and the LEV variable as a dependent variable. They established that the asset structure positively impacted on the financing structure in all company development phases. This means that the greater the share of fixed assets, the smaller the financing structure's share of liabilities. The asset structure's impact on the financing structure is the greatest (based on the variable's regression coefficient) in the group of companies starting the business activity. In the subsequent phases it gradually decreases, which confirms the occurrence of financial difficulties in the initial stages of company development. Another determinant of the financing structure is the operational profitability of assets (cf. Castro, Fernandez, Amor-Tapia and de Miguel). In all the company development phases considered by them, operational profitability had a negative impact on the structure of the capital. The higher the operating profitability, the lower the share of liabilities in the financing structure. This negative relation can be explained by the pecking order theory, according to which companies prefer to use their equity first. From the company size perspective, this theory seems more suited to companies with a stabilised operating and financial situation, i.e. mature companies. Small companies, as well as companies from various sectors of economic activity, may show other dependencies.

In turn, Vithessonthi and Tongurai (2015), in the period 2007-2009, examined over 170 thousand companies from Thailand to find out whether a company's size has an impact on the shaping of the relationship between the financing structure and the profitability of assets. They observed that the literature's discrepancies in the positive or negative relationship between variables might result from this relationship's nonlinear nature. In the case of polynomial relations (e.g. quadratic), there may be a positive relationship in some intervals, while in others - a negative one. Vithessonthi and Tongurai also determined that in small companies, the relation between capital and profitability is positive, whereas in the group of large companies this relation is negative. This observation is in line with the agency theory proposed by Margaritis and Psillaki (2010), who assumed that the independent variable would be the capital structure and the dependent variable - the return on assets in the regression models.

The relations between the ratios representing assets and liabilities of companies are often analysed during studies of net working capital and its impact on companies' results. Thus Afrifa, Tauringana, and Tingbani (2015) examined 1,126 companies from alternative investment markets, 141 of which met the assumed criteria for the availability of financial data over eight years and the definition criteria for small and medium-sized companies. The conducted correlation analysis indicated a positive relationship between the financing structure and the structure of assets. Regression 
analysis showed the LEV variable's statistical irrelevance in the model describing the shaping of the assets' operating profitability. The structure of assets with a negative coefficient was an essential variable in the model.

By analysing a group of 250 companies, Afrifa and Padachi (2016) proved that while the structure of financing is positively correlated with the structure of assets, it is not significantly statistically associated with assets' profitability. The lack of impact of the financing structure on the return on assets disclosed in regression models may suggest restrictions in selecting finance opportunities in the group of small and medium-sized companies.

Klapper, Sarria-Allende and Zaidi (2006) analysed the financing method of Polish companies from the small and medium-sized enterprise sectors. The study covered the period 1998-2002 and the research group comprised over 17,000 companies. The authors determined that larger companies had higher capital structure ratios, while older companies had lower financing structure ratios. The regression analysis also showed positive relationships between the structure of assets and the structure of financing. The main conclusion is that larger, younger, growing and more profitable companies with a larger share of fixed assets make greater use of liabilities as an element of financing. The authors determined the relations between selected variables (company's size, profitability, asset structure) and the shaping of the capital structure in line with leading financial theories - the trade-off and pecking order theories. The authors' predictions indicate a positive relation between the structure of assets and the financing structure in both approaches, which means that fixed assets serve as collateral for the incurred liabilities. According to the pecking order theory, more profitable companies will finance their operations more often using equity. Using the example of Polish small and medium-sized enterprises, the authors showed that the companies' profitability was negatively related to their capital structure, which is another argument for the pecking order theory. In the analysed companies, the structure of assets was positively associated with the financing structure. The authors also found that the larger the share of fixed assets in total assets, the larger the share of long-term liabilities in the financing structure.

Grabiński (2016) (who audited 36,361 financial statements of companies for 2007-2014 from 27 European countries) and García-Teruela and Martínez-Solano (2007) (who audited 8,872 small and medium-sized enterprises in Europe in the period from 1996 to 2002) provided a specific view on the relation between the parameters describing the activity of economic entities. They noted that the return of assets (ROA) is positively correlated with the size of companies and negatively correlated with the debt ratio.

Studies on a group of Polish companies indicate that the financing method's choice cannot be justified based solely on one theory. According the trade-off theory, companies have an optimal financing structure that balances the benefits and costs associated with restrictions on access to capital, and the size of income tax. The existence of an optimal level of financing makes companies focus on achieving this level. Castro et al. (2016) claim that the existence of an optimal level of financing 
does not contradict the pecking order theory. Companies do not aim at the optimal financing level, but maintain the proper relationship between cash flows and investment requirements. Depending on the company's life cycle phase, the benefits and costs of selecting the company's financing sources will change. Growth-phase companies have a large share of fixed assets that mainly act as collateral for foreign financing (Titman \& Wessels, 1988). Additionally, companies in their growth phase are of a size that allows them to be diversified (González \& González, 2008). In their maturity phase, companies have the greater trust of both owners and the market, hence those with higher profitability may be more heavily indebted, benefiting from more considerable tax savings.

The process of capital concentration as a form of further company development should occur while taking internal development opportunities. This situation can take place in the mature phase of a company's life cycle. Numerous studies on the structure of capital most frequently indicate the following set of determinants: profitability (understood as return on assets), the intensity of growth (change in sales), the durability of asset structure, and company size (measured with the total balance sheet assets) (Castro et al., 2016; Mataigne \& Vermaelen, 2016; Zhou, Tan, Faff \& Zhu, 2016). Studies on companies in their maturity phase showed a negative relationship between the structure of capital and companies' profitability. This confirms that companies with a stable position retain a part of the financial result, in line with the pecking order theory, and the relation between the share of fixed assets and the financing structure is positive, while the regression coefficient is smaller than in the growth (initial) phase. This situation also indicates the greater involvement of the funds achieved by companies in fixed assets.

\section{Research methodology}

In the study the authors used a database prepared by InfoCredit SA for the Accountants Association in Poland. The database includes all mergers entered into the National Court Register that were available when creating the database (307 transactions).

The database was adapted to this article's needs, so that all the analysed merger cases covered exactly the five years preceding the mergers. According to the size criterion, the research sample was divided into small and large companies (Table 1). As the companies included in the study are subject to the Polish Accounting Act and the Code of Commercial Companies, this division was based on the Accounting Act guidelines, according to which small companies should not exceed at least two of the following three amounts:

a) PLN 17,000,000 - in the case of total balance sheet assets at the end of the financial year,

b) PLN 34,000,000 - in the case of net revenues from the sale of goods and products for the financial year, 
c) 50 people - in the case of average annual employment calculated as full-time positions. $^{5}$

Due to the lack of information on average annual employment, the total balance sheet criterion and the value of revenues were taken into account in company classification. Companies that did not exceed these two parameters were considered to be small entities, while all the others were included in the group of large companies.

The transition from being small companies to becoming large entities indicates their development in the studied period. Between the fifth and second year before the merger, the size of the large companies' group increased by 28 entities, i.e. by nearly $15 \%$.

All the companies included in the study were also assigned to a relevant sector, based on the first entry in the business entity classification.

The variables used in the study include quantitative and qualitative variables (transformed into binary variables) defining the economic activity sector and the reporting year.

In the group of scientific publications in finance, as many as $74 \%$ of authors, based on research conducted by Berent (2013), measured financial leverage using the $\mathrm{D} /$ $(\mathrm{D}+\mathrm{E})$ measure; $\mathrm{D} / \mathrm{E}(14 \%)$ as well as $\mathrm{D}(10 \%)$ and $(\mathrm{E}+\mathrm{D}) / \mathrm{E}(2 \%)$ were also used. Similar results of the study were obtained by Berent (2013) for financial leverage measures used in accounting journals. Interesting results can be obtained by introducing into the analysis a variable determining the number of years of economic activity of the surveyed economic unit, which allows to examine differences in the behaviour of young and mature companies. In the research conducted by Afrifa and Padachi (2016), a positive relation (correlation matrix) between the operational profitability of assets (ROA) and the variable determining the company's age can be observed.

The literature review shows a positive correlation between the asset structure (often referred to interchangeably as asset sustainability in the literature) and the funding structure (Frank \& Goyal, 2009; Jõeveer, 2013; López-Iturriaga \& Rodriguez-Sanz, 2008). However, the assets structure - such as maintenance costs or depreciation costs - affects companies' business performance. Numerous studies have shown that the relationship between the asset structure and the return on assets is negative (Afrifa \& Padachi 2016; Matias \& Serrasqueiro, 2017). The smaller the share of fixed assets, the higher the companies' profitability from their assets. Based on a literature review covering the period 2004-2016 (Matias \& Serrasqueiro, 2017), it can be concluded that in the different types of companies, the relationship between the asset structure and the financing structure as well as the profitability of the companies, is not unambiguous (i.e. only positive or only negative).

Quantitative variables are:

$$
\text { - ROA ROA }=\frac{\text { Net profit or loss }}{\text { Total assets }} \text {, }
$$

\footnotetext{
${ }^{5}$ Article 3 (1) (c) of the Accounting Act.
} 
- LEV

- $\operatorname{Ln}($ assets)

- $\operatorname{Ln}($ sales $)$

- $\quad$ TANG

$$
L E V=\frac{\text { Liabilities }}{\text { Total assets }},
$$

$$
\operatorname{Ln}(\text { assets })=\ln (\text { Total assets }),
$$$$
\operatorname{Ln}(\text { sales })=\ln (\text { Total revenue }),
$$

$$
T A N G=\frac{\text { Fixed assets }}{\text { Total assets }} .
$$

The verification of the research hypotheses was carried out using Statistica software.

The study used the following statistical tools: Spearman's rank correlation analysis, the Mann Whitney equality median test, the Kołmogorow Smirnow equality mean test, and regression analysis.

\section{Research results}

During the research the authors used commonly accepted determinants of companies' financing structure. First of all the study examined the correlation between variables, emphasising the correlation between the LEV variable and other variables, and Spearman's rank correlation analysis due to being less sensitive to deviations from the linearity of the scatter of variables.

The authors conducted the dependency in the periods preceding mergers, starting five years before the merger and ending two years before it. The groups of small companies and those of large companies were analysed separately.

\section{Five years before the merger - small companies}

Table 2 shows Spearman's rank correlation for small companies five years before the merger.

Based on the table, it was concluded that the LEV variable was significantly correlated with the ROA OP variable only. This correlation is negative, which may mean a decrease in the profitability of assets and debt increase, or vice versa - a lower debt coefficient for more profitable companies. It is worth adding a graphical representation of the relations between variables, which makes it easier to assess the nature of this dependency - linear or non-linear (Figure 1).

An assessment of the nature of the dependency, based on the scatterplot, may not be unequivocal. The authors extended the analysis with a linear and polynomial regression analysis, and based on the results selected the relation, characterised by the greater suitability expressed by the $\mathrm{R} 2$ determination coefficient. An evaluation of the parameters is presented in Tables 3 and 4 . 


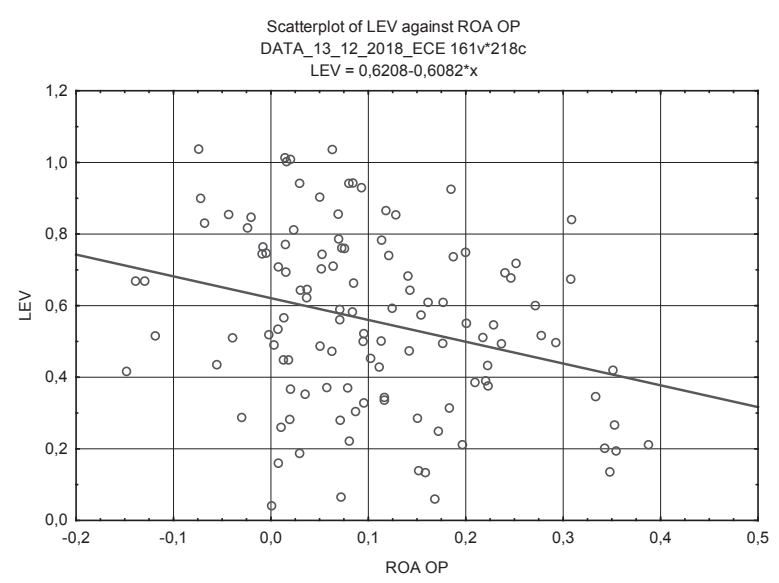

Fig. 1. The scatter of the LEV variable relative to ROA OP

Source: authors' own work.

Based on Table 4, the authors concluded that there is a linear relationship between the ROA OP variable (explanatory variable) and the LEV variable (explained variable).

\section{Five years before the merger - large companies}

Table 5 shows Spearman's rank correlation for large companies five years before the merger.

The LEV variable is correlated with the TANG quantitative and qualitative sector 1 and sector 2 variables (Table 2). Companies belonging to the production sector had a lower share of foreign capital than companies belonging to the commercial sector.

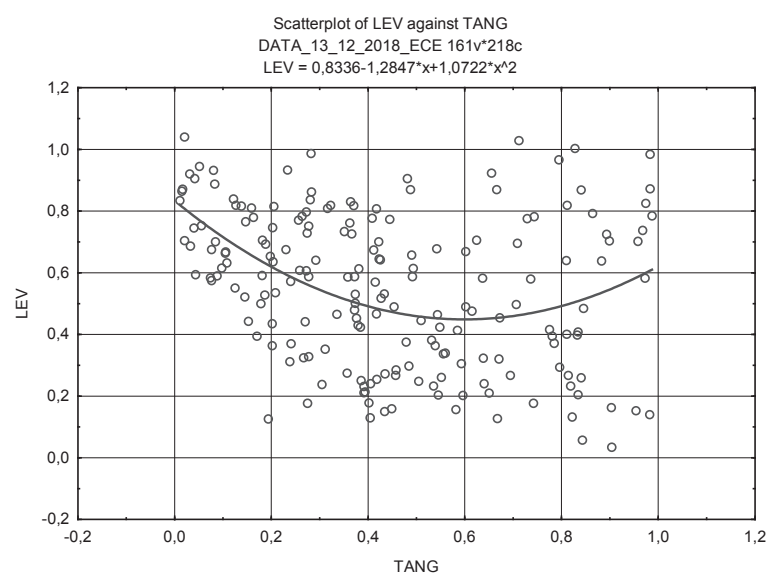

Fig. 2. LEV and TANG variables scatter

Source: authors' own work. 
In addition, an increase in the share of fixed assets in the assets structure impacted on the decrease in the share of liabilities in equity and liabilities. This fact can also be interpreted as the fact that the companies getting into debt allocated funds to current assets, which reduced the share of fixed assets.

The LEV and TANG variables scatter is shown in Figure 2.

Figure 2 shows the polynomial relationship between the LEV and TANG variables. To verify the non-linear nature of the relationship, the authors carried out a linear and polynomial regression analysis: TANG variable (explanatory variable) and LEV variable (explained variable). Table 6 shows the polynomial regression analysis, and Table 8 the linear regression analysis.

The results of the polynomial model regression analysis are presented in Table 7.

The results of the linear model analysis are presented in Table 9.

Based on the regression analysis, the authors concluded that the relationship between the TANG and LEV variables is non-linear with a critical (minimum) point.

\section{Four years before the merger - small companies}

Table 10 shows Spearman's rank correlation for small companies four years before the merger.

There was no statistically significant correlation between the LEV variable and other variables in the group of small companies.

\section{Four years before the merger of large companies}

Table 11 shows Spearman's rank correlation for large companies four years before the merger.

Based on Table 11, it was observed - similarly as in five years before the merger in large companies - that the financing structure was correlated with the economic

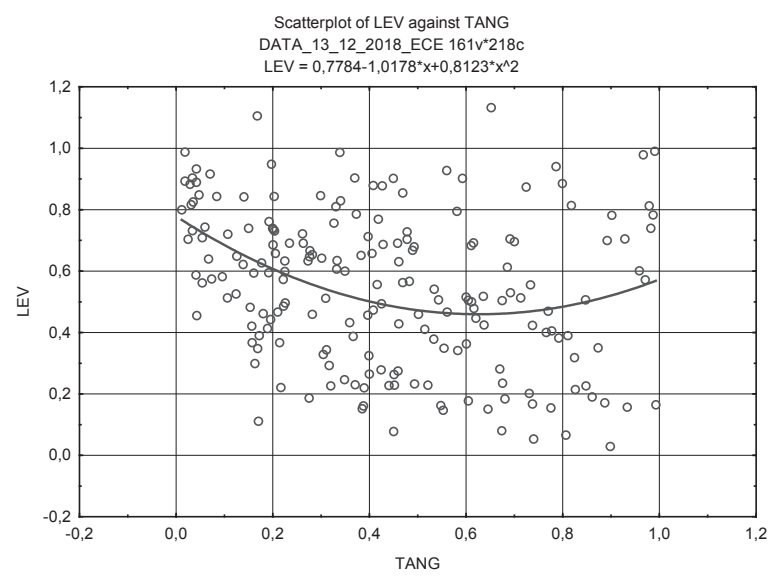

Fig. 3. Scatter of LEV and TANG variables

Source: authors' own work. 
activity sector (sector 1 - negative correlation, sector 2 - positive correlation) and the structure of assets (negative correlation coefficient).

Figure 3 shows the scatter of LEV and TANG variables.

Based on Figure 3, the authors concluded that there is a polynomial relationship between these variables: TANG and LEV.

Table 12 shows the polynomial regression model, and Table 13 summarises the polynomial model. Table 14 provides a summary of the linear model.

Based on the regression analysis, the authors concluded that the determination coefficient is higher in the polynomial model, which means the better suitability of this model to variables.

\section{Three years before the merger - small companies}

Table 15 shows Spearman's rank correlation for small companies three years before the merger.

The correlation analysis in Table 15 indicates that the LEV variable was negatively correlated with the asset structure and positively correlated with the sales volume, which means that companies with higher sales were more indebted. This would be in line with the trade-off theory, in which increased sales and thus tax income would be offset by the higher costs of interest on liabilities. This situation coincides with the initial phase of company life.

Figure 4 shows the scatter of LEV and TANG variables.

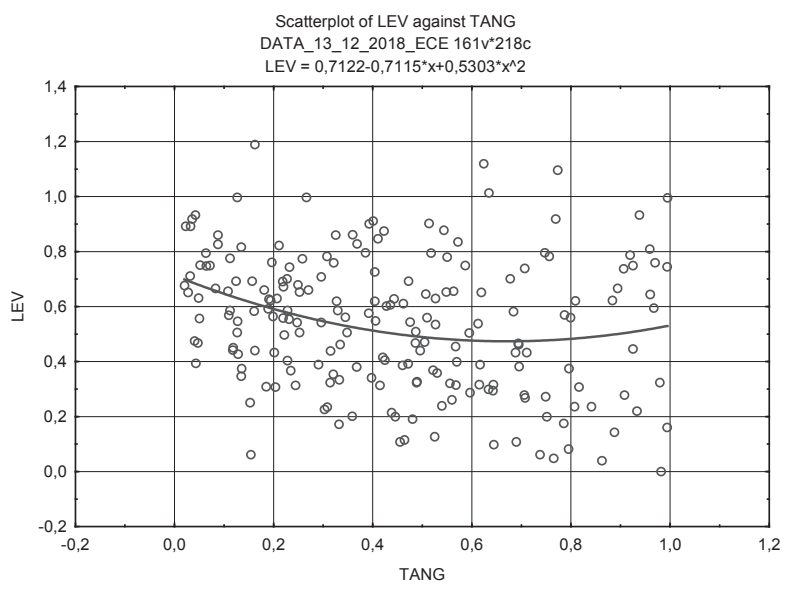

Fig. 4. Scatter of LEV and TANG variables

Source: authors' own work.

Based on Figure 4, the authors concluded that the dependence of the TANG variable (explanatory variable) and the LEV variable (explained variable) is polynomial. An analysis of the summary of regression models (polynomial - Tables 16 and 17, linear - Table 18) indicates a better fit in the polynomial model.

There is no linear relationship between the TANG variable and the LEV variable. 


\section{Three years before the merger of large companies}

Table 19 shows Spearman's rank correlation for large companies three years before the merger.

Based on the correlation analysis in Table 19, the authors concluded that the LEV variable was negatively correlated with the TANG variable and the sector 2 variable. This means that commercial companies had a larger share of liabilities in the financing structure than other companies.

The relation between the TANG and LEV variables is presented in the scatter graph in Figure 5.

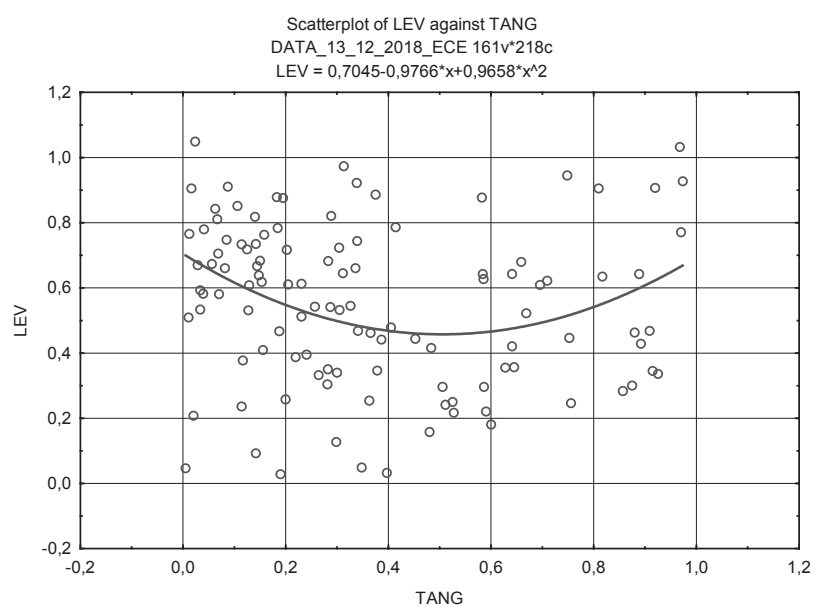

Fig. 5. Relation between the TANG and LEV variables

Source: authors' own work.

Based on Figure 5, the authors observed a polynomial relation between the TANG (explanatory) and LEV (explanatory) variables. Further regression analysis indicates that the only statistically significant model describing these variables is the polynomial model.

Table 21 shows the results of the polynomial regression analysis.

Table 22 shows the results of the linear regression analysis.

\section{Two years before the merger - small companies}

Table 23 shows Spearman's rank correlation for small companies two years before the merger.

A linear regression analysis is presented in Tables 26 and 27.

Based on Tables 24, 25, 26 and 27, the authors concluded that the relation between the LEV and ROA OP variables is linear. 


\section{Two years before the merger - large companies}

Table 28 shows Spearman's rank correlation for large companies two years before the merger.

As in previous periods, two years before the merger in large companies, the financing structure is negatively correlated with the TANG variable and the variable representing the production sector, and positively correlated with the variable representing the commercial sector.

The relation between the LEV and TANG variables is presented in the scatter chart in Figure 6.

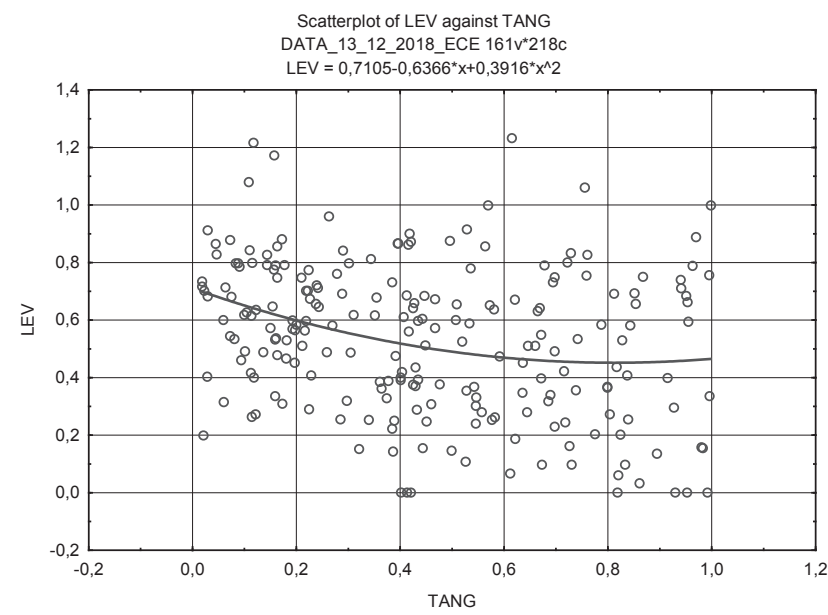

Fig. 6. Relation between the LEV and TANG variables

Source: authors' own work.

Based on Figure 6, one can conclude that the relation is nonlinear, however the summaries of the models (polynomial - Tables 29 and 30) do not confirm that.

A linear regression analysis revealed that the linear model is statistically significant (Tables 31 and 32).

Table 33 presents the correlations of the LEV variable (financing structure) in the group of large companies.

The analysis of the data in Table 33 allows to observe certain regularities in the financing structure. In all the analysed periods there was a negative correlation between the structure of assets and financing structure. This suggests that large companies could finance their investments in fixed assets using the generated financial results, as well as their capital. In addition, a positive correlation between 
the financing structure and the variable representing the commercial sector is visible in all the years. This correlation means that companies from the commercial sector had a larger share of liabilities in the financing structure than other companies. In almost all the analysed periods there was also a negative correlation between the LEV variable and the variable representing the production sector. In this case, production companies preferred higher financing with equity.

In small companies no regularity in the correlation between the LEV variable and other variables can be observed. Table 34 presents the summary of correlation analysis in the group of small companies.

The lack of significant dependence of the financing structure and other parameters of the company's capital may result from the weaknesses and difficulties in conducting business by these entities.

\section{Conclusion}

The article's main objective was to identify the determinants of the financing structure in Polish companies in the periods preceding the mergers of business units. The research sample included 307 Polish acquiring companies was divided into two groups: small companies and large companies.

Based on the presented analyses, the authors concluded that in small companies the explanatory variables identified based on the literature review were statistically insignificant in most periods (almost all). The authors observed completely different behaviour in the group of large companies, where the same set of explanatory variables was statistically significant.

Additionally, during the research the authors discovered that there is no question of a linear nature of dependence in the case of some variables. This situation creates the need to thoroughly analyse the nature of the relation because there may be extremes in the examined parameters. Similarly, the strength of the relation may vary depending on the distance from the extremes of the function.

\section{Tables}

Table 1. Size of the research sample according to the size of the company

\begin{tabular}{|l|c|c|c|c|c|c|c|c|}
\hline \multicolumn{1}{|c|}{ Pre-merger year } & \multicolumn{2}{|c|}{5 years } & \multicolumn{2}{c|}{4 years } & \multicolumn{2}{c|}{3 years } & \multicolumn{2}{c|}{2 years } \\
\hline small/large entity & small & large & small & large & small & large & small & large \\
\hline no. of companies & 190 & 117 & 195 & 112 & 203 & 104 & 218 & 89 \\
\hline Total & \multicolumn{3}{|c|}{307} & \multicolumn{2}{c|}{307} & \multicolumn{2}{c|}{307} & \multicolumn{2}{c|}{307} \\
\hline
\end{tabular}

Source: authors' own work. 


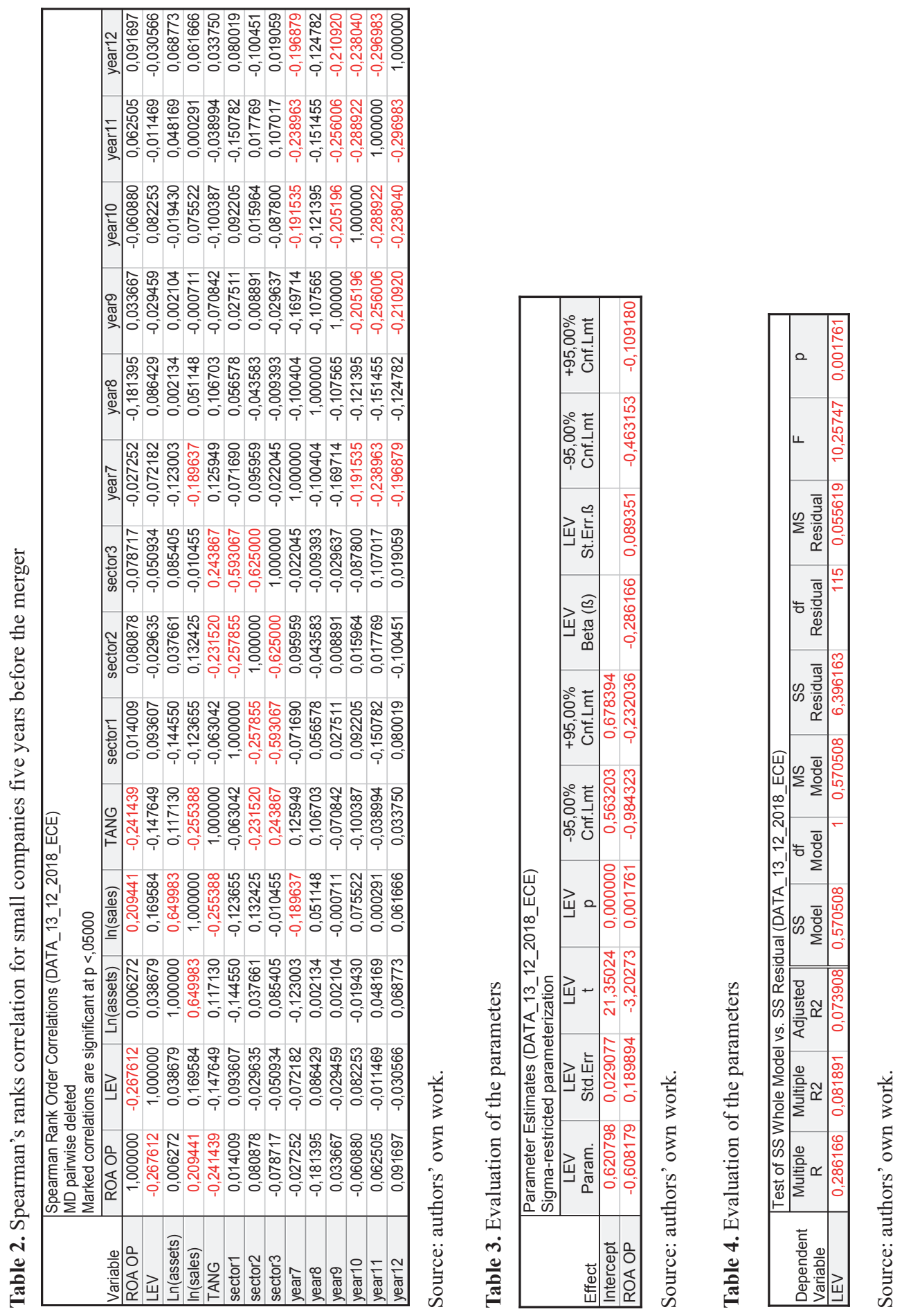




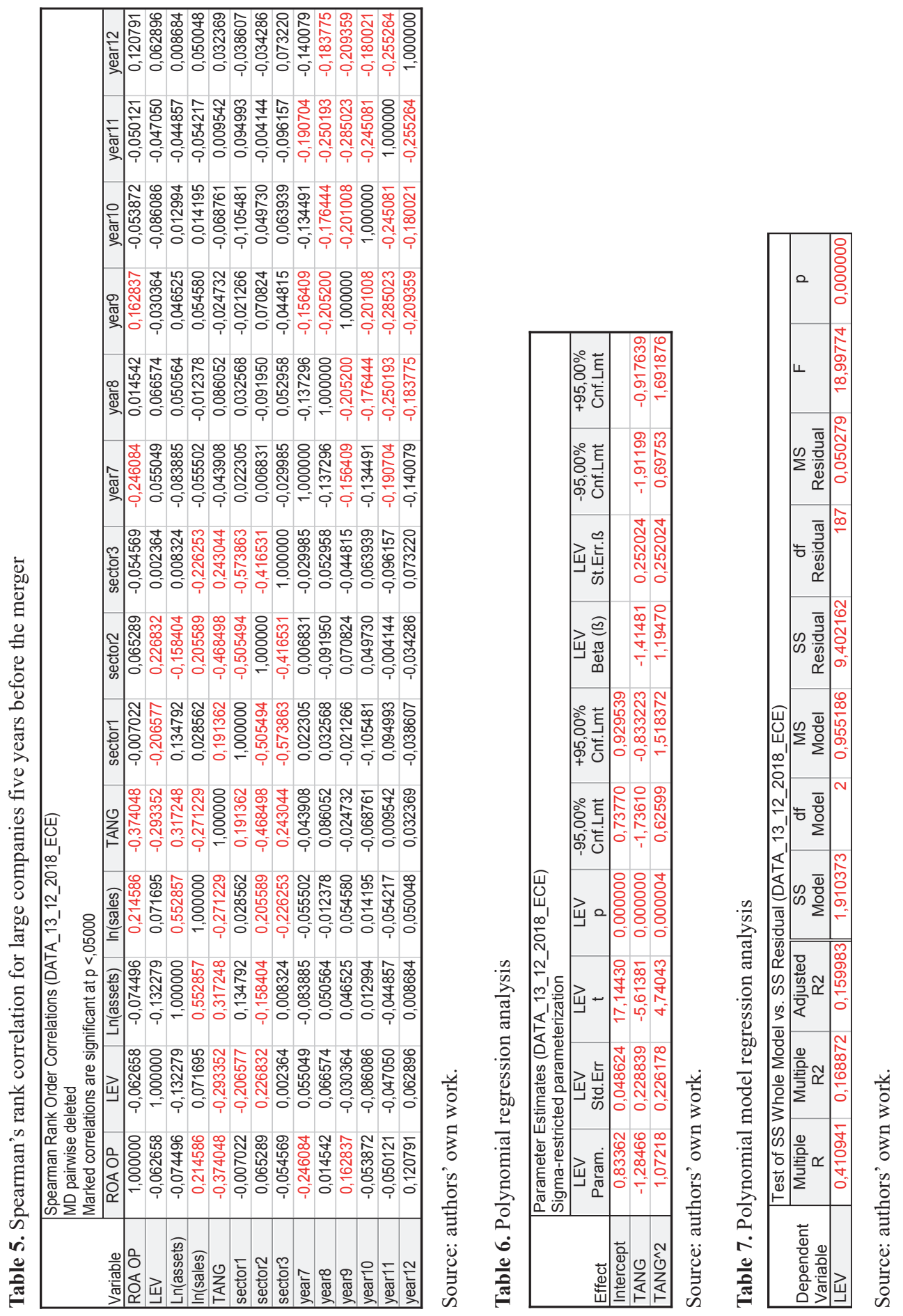



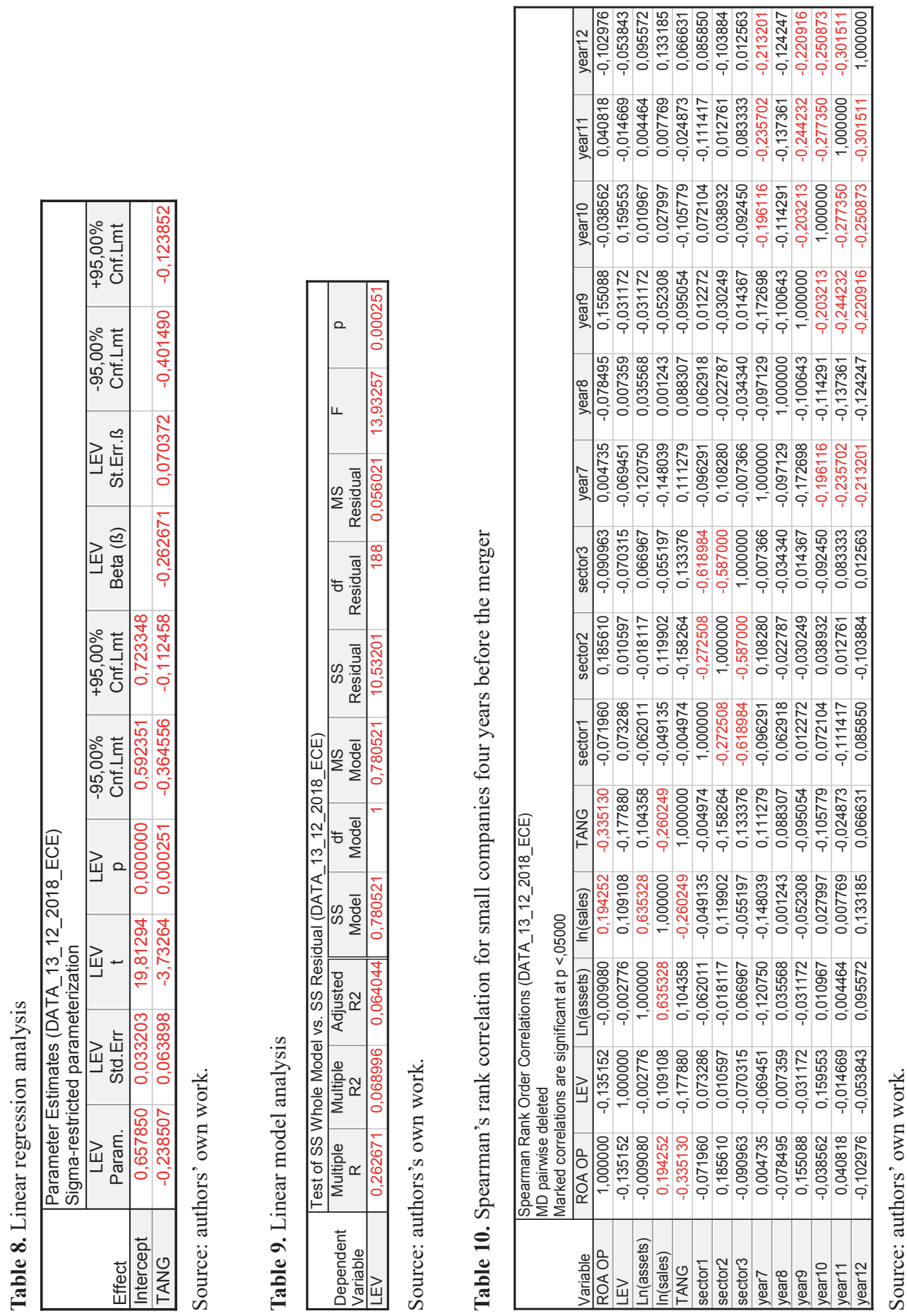


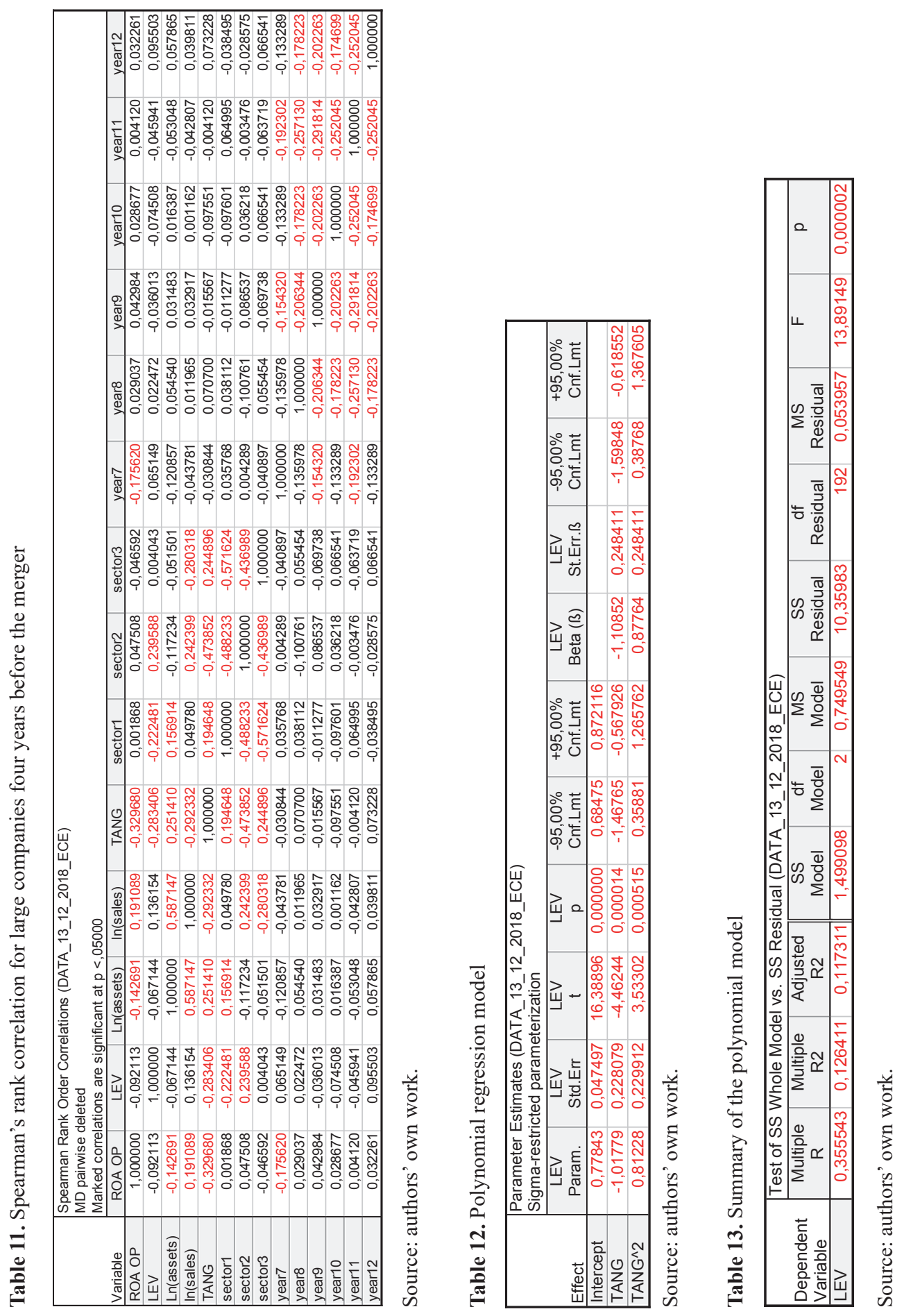



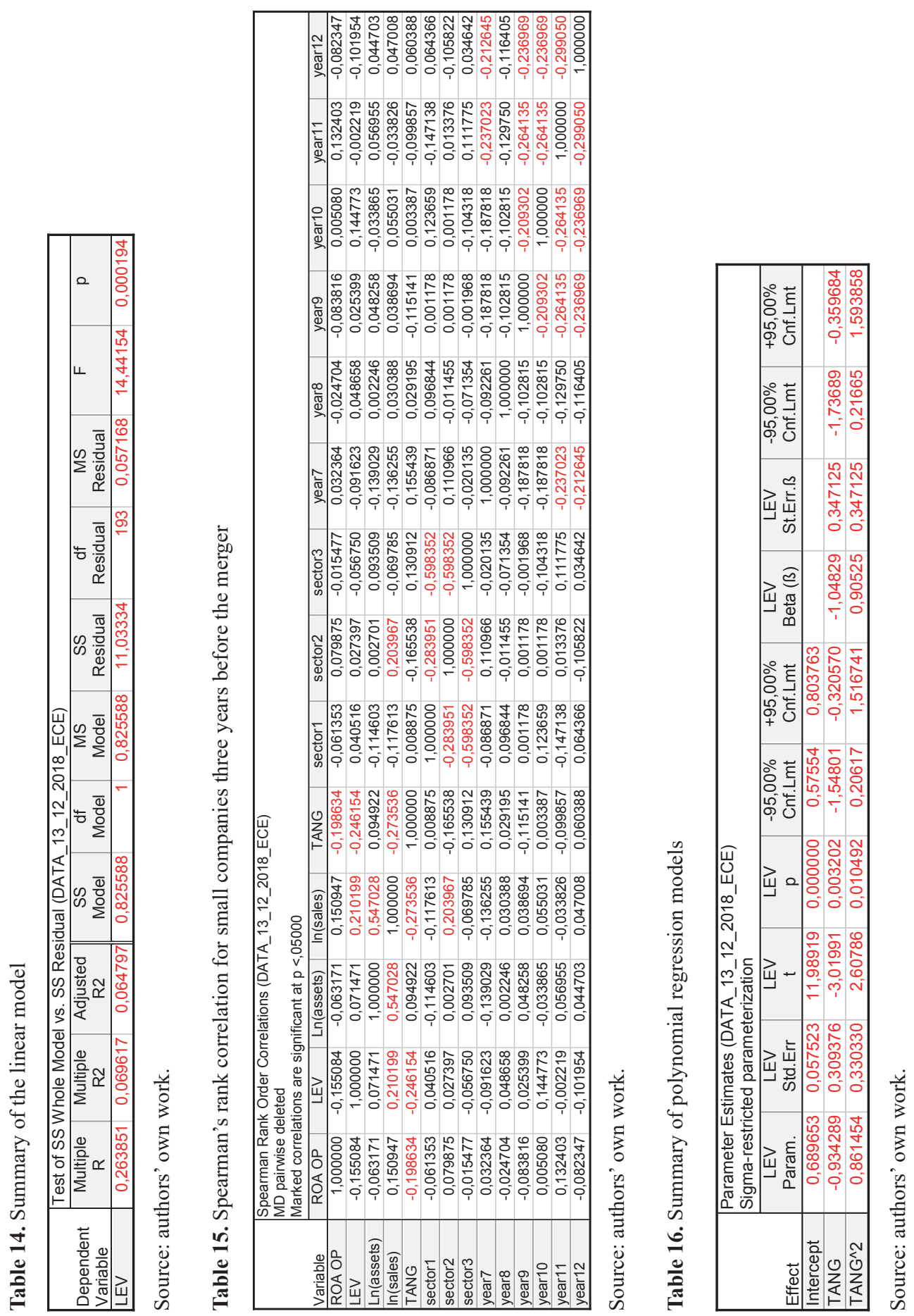

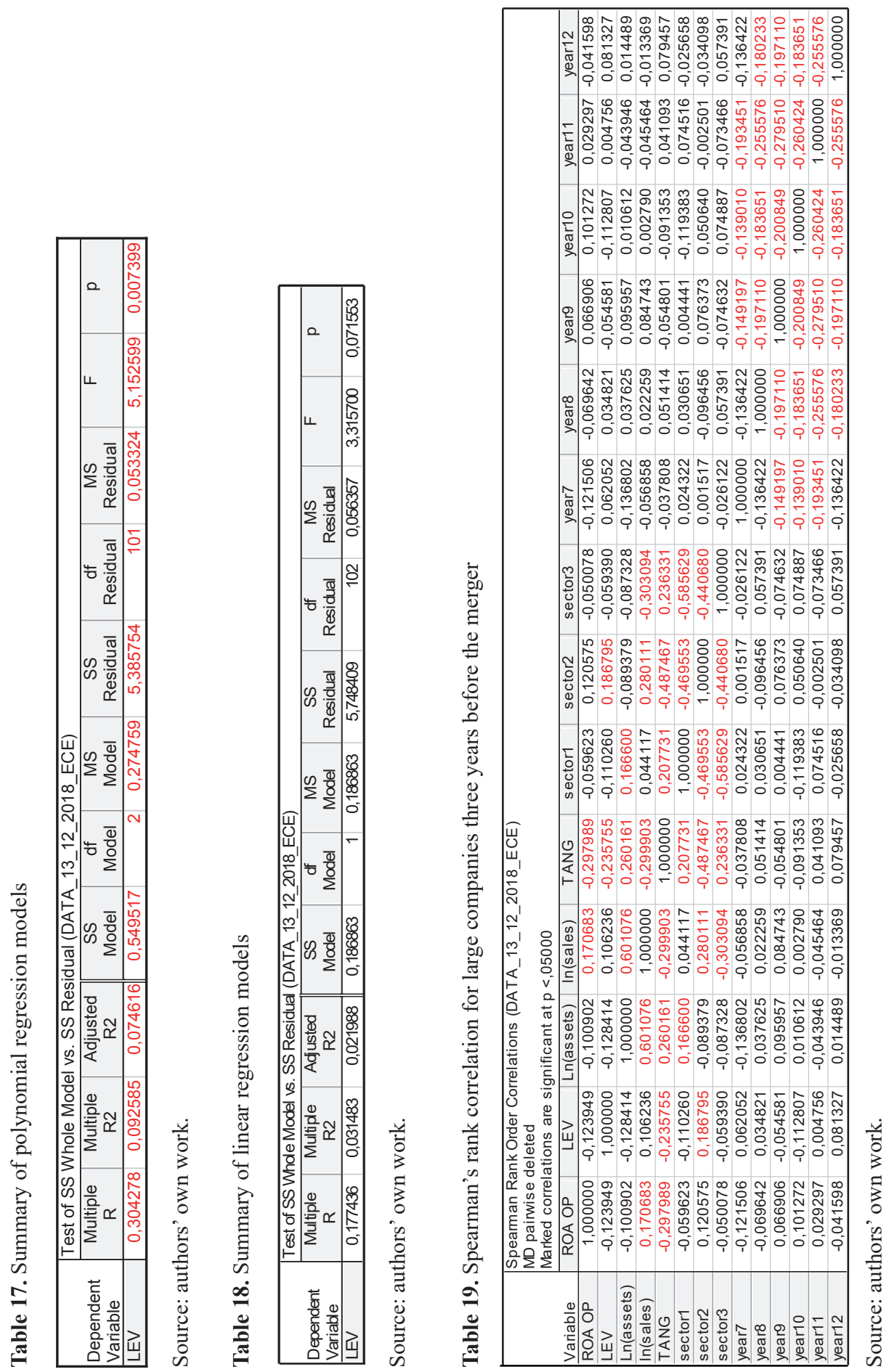

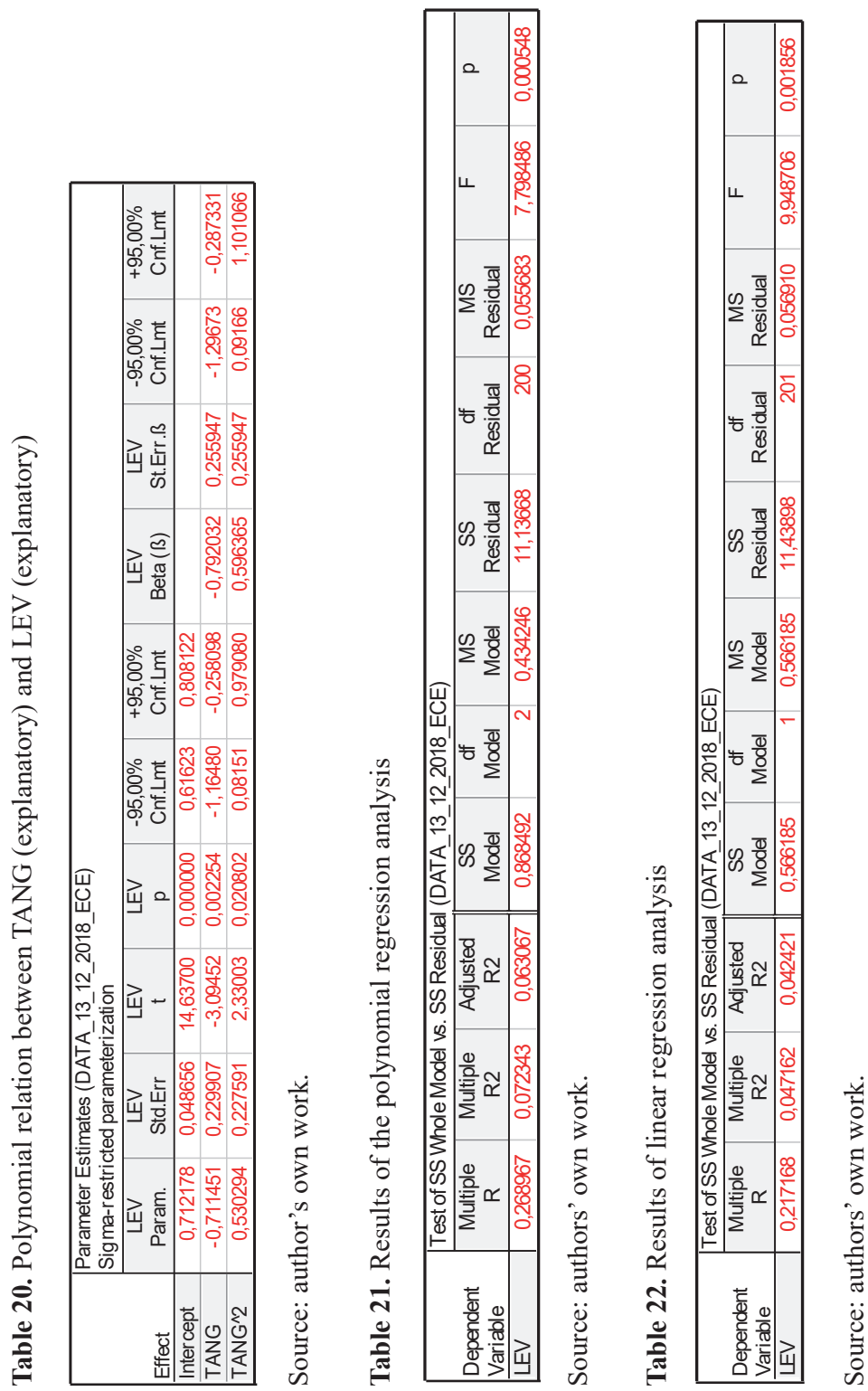

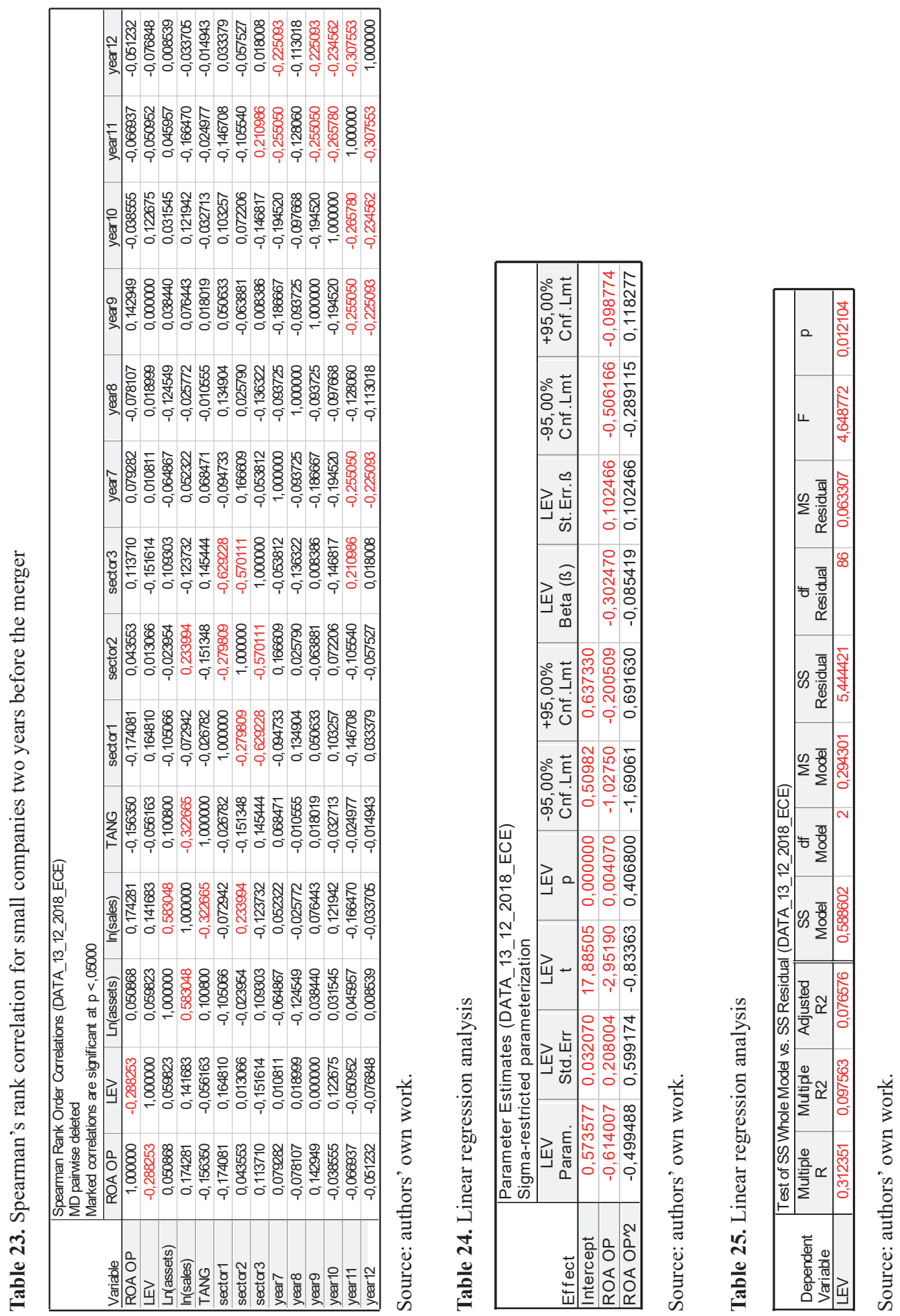

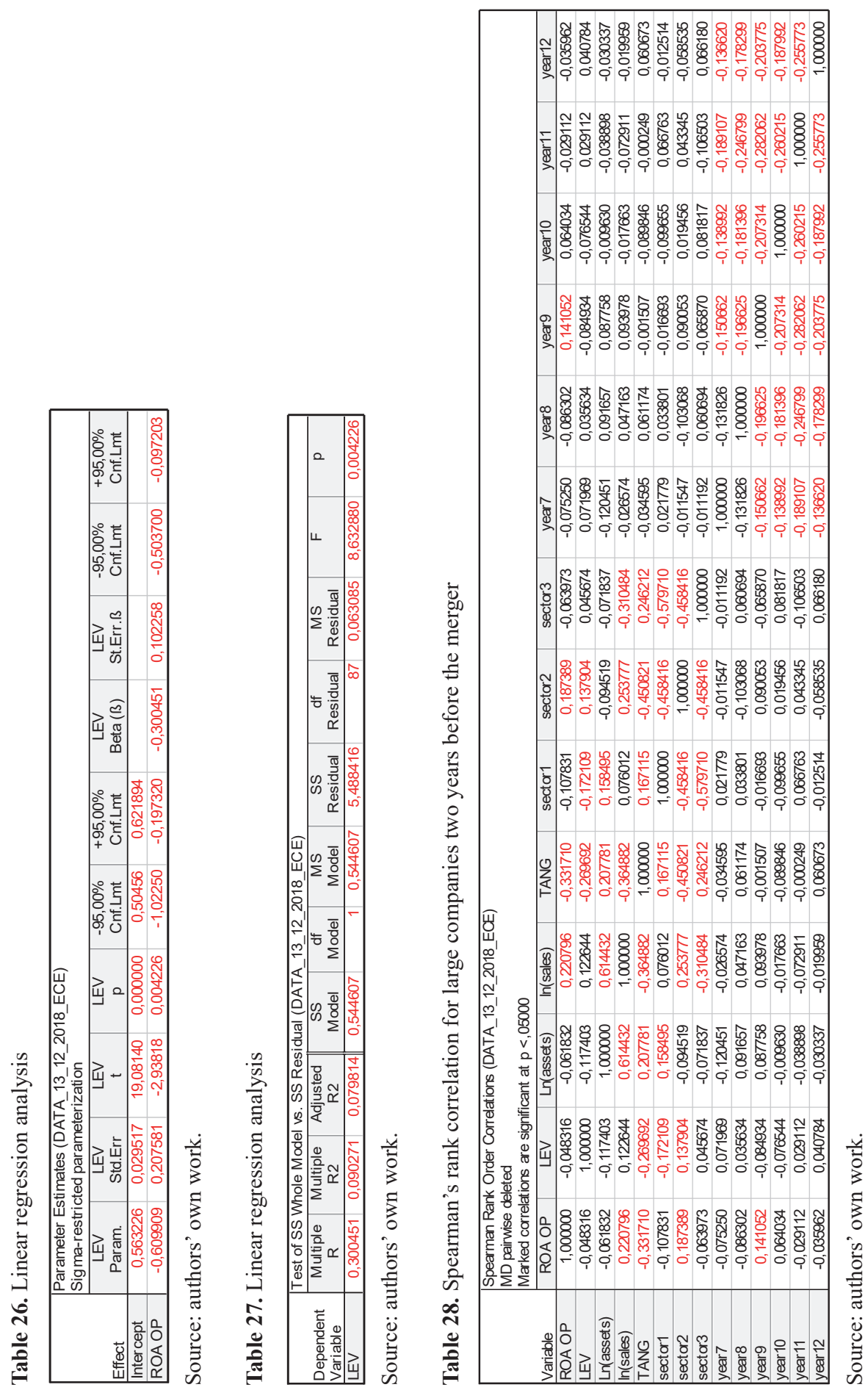

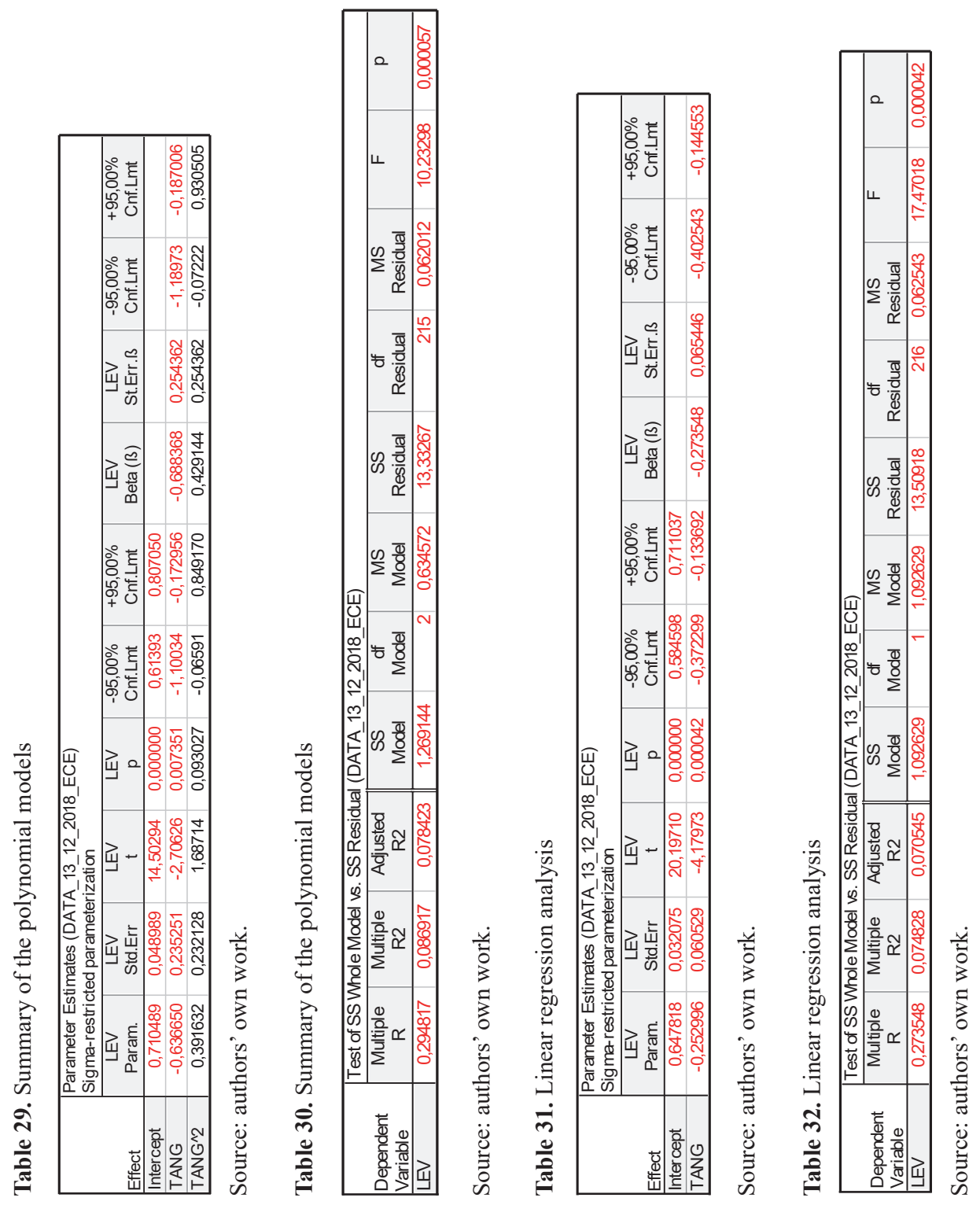
Table 33. Correlations of the LEV variable in the group of large companies

\begin{tabular}{|l|c|c|c|c|}
\hline & 5 & 4 & 3 & 2 \\
\hline TANG & - & - & - & - \\
\hline sector1 & - & - & not signif. & - \\
\hline sector2 & + & + & + & + \\
\hline
\end{tabular}

Source: authors' own work.

Table 34. Summary of correlation analysis in the group of small companies

\begin{tabular}{|l|c|c|c|c|}
\hline & 5 & 4 & 3 & 2 \\
\hline ROA OP & - & not signif. & not signif. & - \\
\hline $\ln$ (sales) & not signif. & not signif. & + & not signif. \\
\hline TANG & not signif. & not signif. & - & not signif. \\
\hline
\end{tabular}

Source: authors' own work.

\section{References}

Acharya, V. V., Shin, H. S., \& Yorulmaz, T. (2010). Fire-sale FDI. Retrieved from https://archive.nyu. edu/handle/2451/29541

Afrifa, G. A., \& Padachi, K. (2016). Working capital level influence on SME profitability. Journal of Small Business and Enterprise Development, 23(1), 44-63.

Afrifa, G. A., Tauringana, V., \& Tingbani, I. (2015). Working capital management and performance of listed SMEs. Journal of Small Business \& Entrepreneurship, 27(6), 557-578.

Aguiar, M., \& Gopinath, G. (2005). Fire-sale foreign direct investment and liquidity crises. Review of Economics and Statistics, 87(3), 439-452.

Ahammad, M. F., Tarba, S. Y., Liu, Y., Glaister, K.W., \& Cooper, C. L. (2016). Exploring the factors influencing the negotiation process in cross-border M\&A. International Business Review, 25(2), 445-457.

Berent, T. (2013). Ogólna teoria dźwigni finansowej. Warszawa: Szkoła Główna Handlowa w Warszawie - Oficyna Wydawnicza.

Brunnermeier, M. K., (2005). Information leakage and market efficiency. The Review of Financial Studies, 18(2), 417-457.

Caiazza, R., \& Volpe, T. (2015). M\&A process: A literature review and research agenda. Business Process Management Journal, 21(1), 205-220.

Castro, P., Fernández, M. T. T., Amor-Tapia, B., \& de Miguel, A. (2016). Target leverage and speed of adjustment along the life cycle of European listed firms. BRQ Business Research Quarterly, 19(3), 188-205.

Cornett, M. M., McNutt, J. J., Strahan, P. E., Tehranian H. (2011). Liquidity risk management and credit supply in the financial crisis. Journal of Financial Economics, 101(2), 297-312.

De Bernardis, L., \& Giustiniano, L. (2015). Evolution of multiple organisational identities after an M\&A event: A case study from Europe. Journal of Organizational Change Management, 28(3), 333-355.

Desai, M. A., Foley, C. F., \& Forbes, K. J. (2007). Financial constraints and growth: Multinational and local firm responses to currency depreciations. The Review of Financial Studies, 21(6), 2857-2888. 
Feldman, R. A., \& Kumar, M. S. (1995). Emerging equity markets: Growth, benefits, and policy concerns. The World Bank Research Observer, 10(2), 181-200.

Frank, M. Z., \& Goyal, V. K. (2009). Capital structure decisions: Which factors are reliably important? Financial Management, 38(1), 1-37.

Friedman, Y., Carmeli, A., Tishler, A., \& Shimizu, K. (2016). Untangling micro-behavioral sources of failure in mergers and acquisitions: A theoretical integration and extension. The International Journal of Human Resource Management, 27(20), 2339-2369.

García-Teruel, J. P., \& Martinez-Solano, P. (2007). Effects of working capital management on SME profitability. International Journal of Managerial Finance, 3(2), 164-177.

Ghosh, A. (2001). Does operating performance really improve following corporate acquisitions? Journal of Corporate Finance, (7), 151-178.

González, V. M., \& González, F. (2008). Influence of bank concentration and institutions on capital structure: New international evidence. Journal of Corporate Finance, 14(4), 363-375.

Grabiński, K. (2016), Determinanty kształtowania wyniku finansowego w teorii i praktyce europejskich spółek giełdowych. Zeszyty Naukowe Uniwersytetu Ekonomicznego w Krakowie. Monografie, (245).

Heron, R., \& Lie, E. (2002). Operating performance and the method of payment in takeovers. Journal of Financial and Quantitative Analysis, (37), 137-156.

Jõeveer, K. (2013). What do we know about the capital structure of small firms. Small Business Economics, 41(2), 479-501.

Klapper, L., \& Love, I. (2004). Corporate governance, investor protection, and performance in emerging markets. Journal of Corporate Finance, Amsterdã, 10(5).

Klapper, L., Sarria-Allende, V., \& Zaidi, R. (2006). A firm-level analysis of small and medium size enterprise financing in Poland. The World Bank.

Krugman, P. (2000). Fire-sale FDI. In S. Edwards (Ed.), Capital flows and the emerging economies: Theory, evidence, and controversies. University of Chicago Press.

Lee, J., Park, K. N., \& Kim, H. (2014). The effect of change in organizational identity on knowledge creation by mobile R\&D workers in M\&As. Journal of Organizational Change Management, 27(1), 41-58.

Linn, S. C., \& Switzer, J. A. (2001). Are cash acquisitions associated with better postcombination operating performance than stock acquisitions? Journal of Banking and Finance, 6, 1113-1138.

López-Iturriaga, F. J., \& Rodriguez-Sanz, J. A. (2008). Capital structure and institutional setting: A decompositional and international analysis. Applied Economics, 40(14), 1851-1864.

Makaew, T. (2010). The dynamics of international mergers and acquisitions. Retrived from https://papers.ssrn.com/sol3/papers.cfm?abstract_id=1572005

Margaritis, D., \& Psillaki, M. (2010). Capital structure, equity ownership and firm performance. Journal of Banking \& Finance, 34(3), 621-632.

Martynova, M., Oosting, S., \& Renneboog, L. (2006). The long-term operating performance of European mergers and acquisitions (ECGI - Finance Working Paper No. 137/2006, TILEC Discussion Paper No. 2006-030). Retrieved from https://ssrn.com/abstract $=944407$

Mataigne, V., \& Vermaelen, T. (2016). Acquisition finance: Are European companies different? (NSEAD Working Paper No. 2016/43/FIN). Retrieved from https://ssrn.com/abstract=2801466

Matias, F., \& Serrasqueiro, Z. (2017). Are there reliable determinant factors of capital structure decisions? Empirical study of SMEs in different regions of Portugal. Research in International Business and Finance, (40), 19-33.

McCann, M., \& Ackrill, R. (2015). Managerial and disciplinary responses to abandoned acquisitions in bidding firms: A new perspective. Corporate Governance: An International Review, 23(5), 402-416.

Moeller, S. B., \& Schlingemann, F. P. (2004). Are cross-border acquisitions different from domestic acquisitions? Evidence on stock and operating performance for U.S. acquirers. Journal of Banking and Finance. 
Munjal, S., \& Pereira, V. (2015). Opportunities and challenges for multiple-embeddedness through mergers and acquisitions in emerging economies. Journal of Organizational Change Management, 28(5), 817-831.

PARP. (n.d.). Retrieved from https://www.parp.gov.pl/images/PARP_publications/pdf/parp_4_raport $\% 20$ o $\% 20$ stanie $\% 20$ sektora $\% 20$ maych $\% 20 \mathrm{i} \% 20$ srednich $\% 20$ przedsieb $\% 20$ w $\% 20$ polsce_internet.pdf

Porta, R. L., Lopez-de-Silanes, F., Shleifer, A., \& Vishny, R. W. (1998). Law and finance. Journal of Political Economy, 106(6), 1113-1155.

Powell, R. G., \& Stark A. W. (2005). Does operating performance increase post-takeover for UK takeovers? A comparison of performance measures and benchmarks. Journal of Corporate Finance, (11), 293-317.

Reddy, K. S. (2015). The state of case study approach in mergers and acquisitions literature: A bibliometric analysis. Future Business Journal, 1(1-2), 13-34.

Titman, S., \& Wessels, R. (1988). The determinants of capital structure choice. The Journal of Finance, 43(1), 1-19.

Vithessonthi, C. \& Tongurai, J. (2015). The effect of firm size on the leverage-performance relationship during the financial crisis of 2007-2009. Journal of Multinational Financial Management, 29, 1-29.

Weitzel, U., \& McCarthy, K. J. (2011). Theory and evidence on mergers and acquisitions by small and medium enterprises. International Journal of Entrepreneurship and Innovation Management, 14(2-3), 248-275.

Zhang, W., Wang K., Li L., Chen Y., \& Wang X. (2018). The impact of firms' mergers and acquisitions on their performance in emerging economies. Technological Forecasting and Social Change, (5).

Zhou, Q., Tan, K. J. K., Faff, R., \& Zhu, Y. (2016). Deviation from target capital structure, cost of equity and speed of adjustment. Journal of Corporate Finance, 39, 99-120.

\section{CZYNNIKI KSZTALTUJĄCE STRUKTURĘ KAPITALU W SPÓŁKACH PRZEJMUJĄCYCH W OKRESIE POPRZEDZAJĄCYM POLĄCZENIE PODMIOTÓW GOSPODARCZYCH}

Streszczenie: Podstawowe cele artykułu to identyfikacja czynników determinujących kształtowanie struktury finansowania oraz określenie ich zmian w okresach przed połączeniem w spółkach dokonujących przejęć. Badając strukturę finansowania, sprawdzono również, jakie relacje zachodzą w różnych sektorach aktywności gospodarczej. Udzielono odpowiedzi na pytania, czy i w jaki sposób wielkość spółek determinuje kształtowanie struktury kapitału. Analizą objęto pięć lat poprzedzających transakcje połączenia 307 jednostek gospodarczych. Źródłem danych badania była baza danych przygotowana przez spółkę InfoCredit SA na zlecenie Stowarzyszenia Księgowych w Polsce. W pracy wykorzystano oprogramowanie Statistica. Zastosowano wnioskowanie indukcyjne wsparte analizą korelacji rang Spearmana, analizą regresji liniowej i wielomianowej oraz analizą rozrzutu zmiennych.

Słowa kluczowe: M\&A, struktura kapitału, finansowanie działalności goposdarczej. 